石油技術協会誌 第 39 巻 第 3 号 (昭和 49 年 5 月)

JOURNAL OF THE JAPANESE ASSOCIATION OF PETROLEUM TECHNOLOGISTS

VOL. 39 NO. 3 (May 1974)

新潟県中部・北部地域の含油新第三系の層序

新潟県中越・下越地方の石油地質学的研究(その I )-

片 平 忠 実*

（昭和 49 年 4 月 15 日受理）

\title{
Stratigraphy of the Neogene Tertiary in the Central and the Northern Parts of Niigata Prefecture
}

-Petroleum Geology of the Neogene Tertiary in the

Chuetsu and the Kaetsu Regions, Niigata, Japan-

(Part I)

By

Tadami KATAHIRA

\begin{abstract}
Owing to the recent advancements in technology of geophysical exploration and drilling, many geological data concerning to the deep seated formations have been accumulated. Recent studies about surface and subsurface geology and about planktonic foraminiferal fossils have made clear the lower and middle Miocene stratigraphy. The writer proposes, in this paper, to divide the Miocene to lower Pleistocene formations into 7 stages in this district.

Stage I-Mikawa stage (lower to middle Miocene)

Formations included in this stage are the Aikawa group (Sado Island), Matsukawa group (Kita-Uonuma County) and Jonai group (Minami-Uonuma County). The formations consist mainly of pyroclastic rocks (lower part of the "green tuff") including propyrite and contain Aniai-type flora in the intercalating non-marine-shallow marine sediments.

Stage II-Nanatani stage (middle Miocene)

Lithology of the formations of this stage is composed of various kinds of pyroclastic rocks (upper part of the "green tuff"), coarse clastic sediments which may have been deposited in the shallow marine and fine clastic sediments of rather deep marine origin.

This stage belongs to Globorotalia fohsi zone and Hopkinsina morimachiensis - Gyroidina orbicularis zone. Fossils such as Daijima-type flora, Miogypsina-Operculina fauna, AcidPotamid fauna and Pectinid fauna characterize this stage.

According to planktonic foraminiferal zonation newly established by Japex's paleontologists, the Iwafune group, the Tsugawa formation and the Nanatani formation, which had been considered to be deposited in this order and to be unrelated stages, have been concluded to constitute only one stage. However, in Akita region, two stages are recognized in the age corresponding to the stage II of this province. To solve this discrepancy, more detailed studies should be carried out.

Stage $\mathbb{I}$-Teradomari stage (lower part of the upper Miocene)

Main lithology is black mudstone being deposited under stagnant water. Benthonic foraminiferal fauna is mostly composed of arenaceous forms belonging to Spirosigmoilinella compressaMartinottiella communis zone.

In the area west of the Nagaoka plain, alternations of sandstone and mudstone are predominant and some planktonic foraminifers with calcareous benthonic forms are found.

Volcanic rocks mainly of andesite and dacite are found in places. Submarine eruption and intrusion of basalt are highly characteristic in this stage.

Stage $\mathbb{N}$-Shiiya stage (upper Miocene)
\end{abstract}

* 石油資源開発(株) 
Lithology is alternation of sandstone/mudstone and mudstone. The former is called Shiiya alternation and the latter, being grey mudstone, called Araya mudstone.

Benthonic foraminifers are characterized by coexistence of arenaceous and calcareous forms of Miliammina echigoensis zone. Planktonic foraminiferal zone is "Orbulinna" universa-Globigerina woodi zone which contains Globigerina pachyderma (dextral) and Globorotalia inflata.

It is noted that the volcanic activity subsided during this stage as compared with the previous stages. Andesitic and dacitic pyroclastic rocks are found in some places.

Stage $\nabla$-Nishiyama stage (lower Pliocene)

Characteristic lithology is greenish grey mudstone named the Nishiyama mudstone. Frequently, especsally in the lower part of this stage, alternation of sandstone and mudstone, so called the Hamatsuda alternation, is found.

The middle and the lower parts of this stage are distinguished by Globigerina pachyderma (dextral) - Globorotalia inflata (s.l.) zone, in which Globorotalia inflata group appears in two zones. Coiling direction of fossil Globigerina pachyderma changes from dextral to sinistral at the middle of this stage. The upper part of this stage belongs to Globigerina pachyderma (sinistral) - Globigerina qninqueloba zone.

According to benthonic foraminiferal zonation, this stage corresponds to Uvigerina akitaensis - Islandiella japonica zone.

Pyroclastic rocks consisting mainly of andesite and dacite are found in many places.

Stage 7 -Haizume stage (upper Pliocene-lowest Pleistocene)

Main lithology is grey siltstone which is famous as the Haizume formation. Partially, especially at the basin margin, sandy member named the Wanazu member and conglomeratic member of the Tsukayama member are recognized.

Globigerina pachyderma (sinistral)-Globigerina incompta zone indicates this stage. Occasionally, Globorotalia inflata and dextrally coiled Globigerina pachyderma occur at the base of this stage. Protoelphidium clavatum-Pseudorotalia gaimardii zone is the benthonic foraminiferal zonation of this stage.

Volcanic rocks such as dacite are found in limited areas.

Stage VII-Oguni stage (Pleistocene)

Most of the sediments of this stage are composed of non-marine or brackish water sediments such as conglomerate, sandstone with lignite seams. At the center of the basin, marine environment seems to have remained although the sediments are mostly coarse.

Geologic age was inferred with dependence on the worldwide correlation of planktonic foraminifera chiefly studied by K. Shinbo and S. Maiya. Some data from radiometric dating such as fission track method and $\mathrm{K}-\mathrm{Ar}$ method were accepted. Fossils of mammals, though they are very scarcely found in the Pliocene and Pleistocene beds in this area, are also very useful for this purpose.

\section{1. 緒言}

近年，物理探鉱および掘さくの技術が向上して，深部 層の地質情報が著しく増加してきた。ことに，1958年， 見附油田が発見されて以来, グリンタフが本地域の主要 探鉱対象層準となり，最近では，新第三系上部層が厚く て掘さく機の能力を越える場合を除き，試掘井はグリン タフまで掘り込むように計画されている。

今日までに,グリンタフに到達した坑井は 200 坑に及 び，14坑は基盤岩に到達している。これらの坑井資料に よって, 従来は新潟堆積盈地の東縁部や佐渡など, 地層 が露出している地域でしか研究できなかった新第三系下 部の層序・岩相分布が全域にわたって解明されつつあ る。これには，最近における浮遊性有孔虫化石に関する
研究の進歩が大いに寄与している。

本論文では, グリンタフ層準に関して最近得られた新 知見を中心に，本地域の層序をレビューし，な打残され ている問題点を指摘する（第 1 図）。

\section{謝 辞}

本論文を草するに当り，貴重な資料と有益な助言を頂 いた，石油資源開発株式会社の猪間明俊・森田謙宏・新 保久弥・米谷盛寿郎各氏, 本論文の公表を許可された, 同社取締役の池辺稞博士に感謝する。

\section{2. 層序}

標準層序を第 1 表に示す。層序の編集に当っては，近 年, 調査・研究の進んだ浮遊性有孔虫化石による生層 序，放射年代の資料を考慮した。 
第1図索引 図
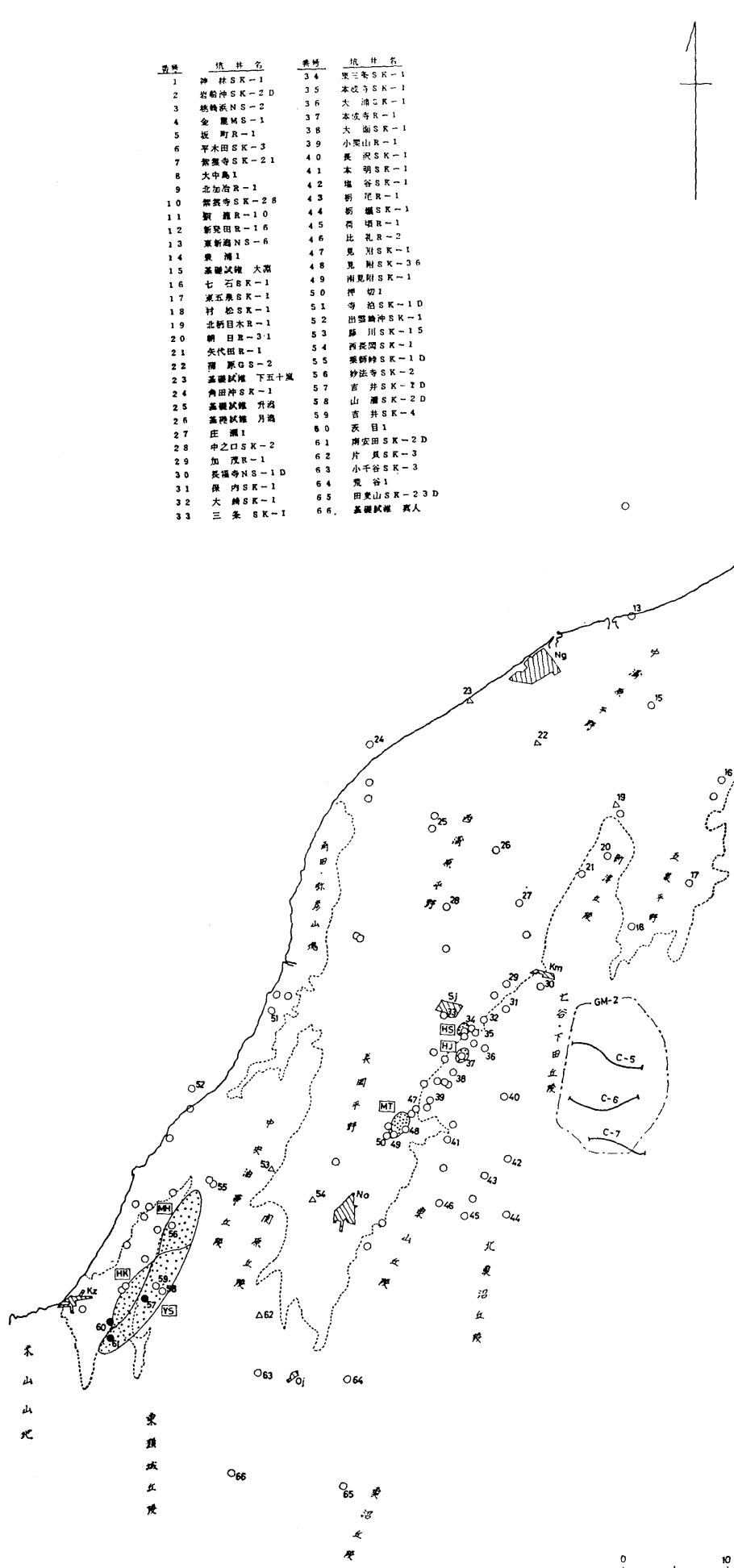
第 1 表 新潟堆皘盆地の新第三系層序表

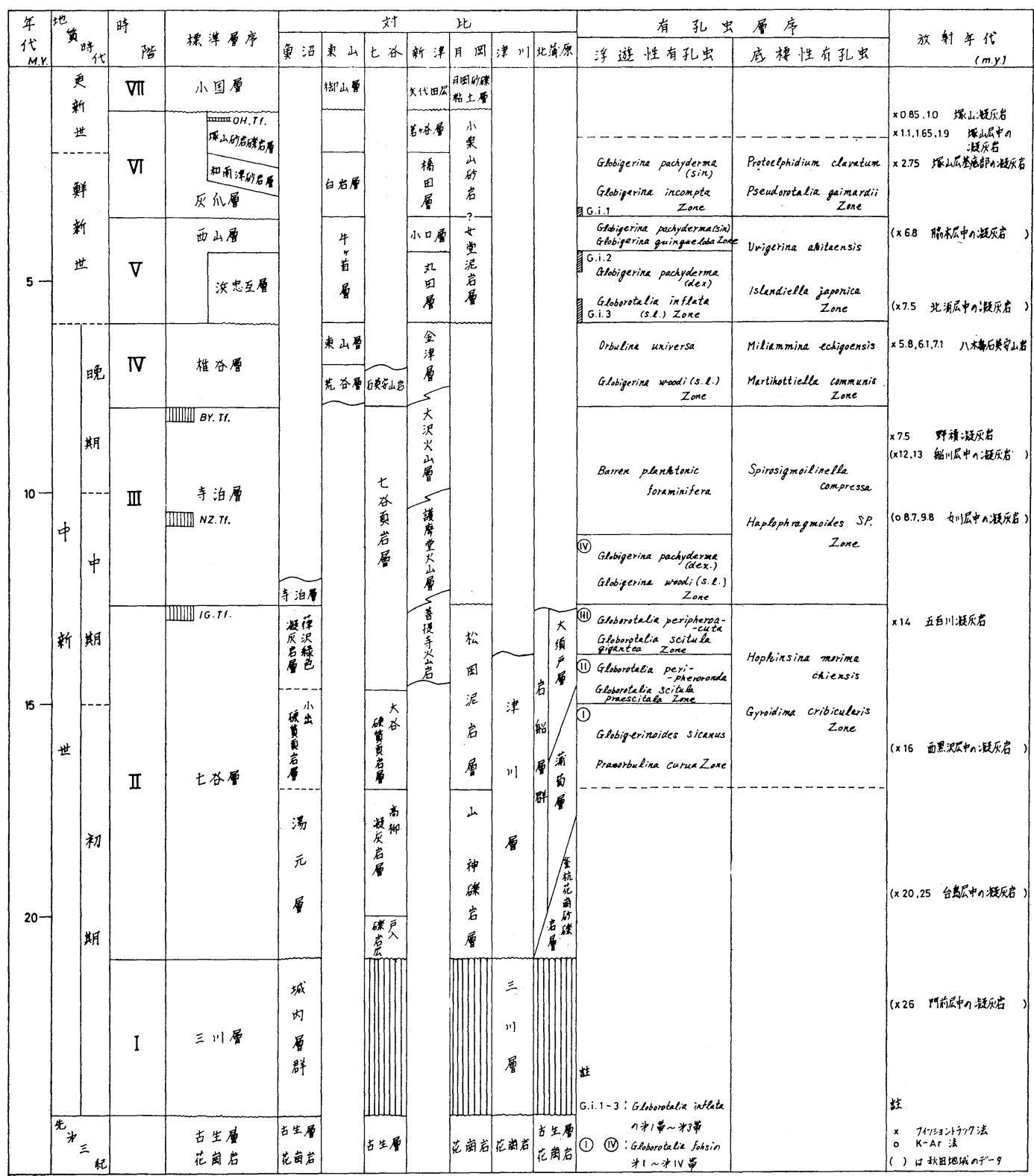

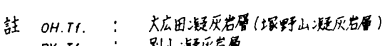

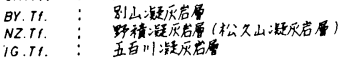

\section{1. 基盤岩類}

古生層和よび花㶡岩類から成り，北蒲原北部，同東部 櫛形山脈, 五頭山塊, 五泉平野東縁, 七谷一下田丘陵東 縁などに露出している。

古生層はいわゆる秩父古生層で, 粘板岩・砂岩を主と し，チャート・石灰岩を挟んでいる。花崗岩はこの古生 層に貫入したもので，貫入時期は一般に白亜紀といわれ
ている。

基盤岩は平野部の坑井に打いても認められる。古生層 の粘板岩・砂岩で，ときにホルンフェルス化しているも のと, 花崗岩類が主たるものである。北蒲原平野では, 9 坑井が基盤岩に達している。本地域南部の中央油帯地 区では 3 坑井が基盤岩に達し, そのうち 1 坑では花崗岩, 2 坑では超塩基性の蛇紋岩・輝岩であった。 
中生代抒よび古第三紀の地層は油田地帯で認められて 抢らず，新第三紀層が上述の基盤岩類を直接不整合にお おっている。

\section{2. 第 I 階（三川階）}

新潟地域の新第三系下部に発達する火山䂶屑岩類，い わゆるグリンタフのうち，下部を占めるもので，阿仁合 型フロラに相当する化石植物群を含むもの，岩相上それ に対比されるものを本階の地層とした。

明瞭な阿仁合型フロラは佐渡の相川層群に含まれる関 化石植物群で, 同島の変質火山岩類の大部分は本階に含 まれるものと考兄られる。

三川盆地には変朽安山岩を主とするグリンタフと，砂 岩・砂岩・泥岩の厚い互層が発達して括り，三川層(群) と呼ばれている。泥岩層の中から植物化石 Marlea aequalifolia (Göpp.) を産し22)，これが阿仁合型フロ ラの構成種であること，上位層と構造的に不調和であ り，かつ岩相的にも著しく異なるため，三川層を相川層 群に対比した。

化石的証拠はないが，北魚沼郡の松川層，南魚沼郡の 城内層などは火山砕首岩類が著しく変質を受けており， 堆積岩類も続成作用が進んでいるため, 本階の地層と考 えられる。

第 I 階の地層は新潟堆積盈地の周縁に露出している。 坑井では, 吉井ガス田に打いて, 岩相からみて城内層群 であろらと考觉られる砂岩・泥岩互層が認められてい る。

新潟地域では，本階に属する岩層の放射年代はまだ計 測されていない。これに対比されている秋田県男鹿半島 の門前層中の凝灰岩について，西村進 ${ }^{84)}$ がフィッション トラック法で測定した数值は 2,600 万年である。

\section{3. 第 II 階（七谷階）}

本階の地層は，主として酸性ないし中性火山竖拉よび 火山砕屏岩類，いわゆるグリンタフの上半部と，浅海成 の砂岩・磁岩層拈よびやや深い海底で堆積した泥岩層で ある。

火山砕首岩類のかなりの部分は, 最近の研究によっ て，水中破砕熔岩流であることが指摘されている。第 I 階のグリンタフに比し, 変質の程度は全般に弱い。本地 域内に広く分布し，主要な貯留岩となって和り，紫雲寺 凝灰岩層, 小栗山凝兏岩層, 見附凝灰岩層, 吉井凝灰岩 層などと個有の名称で呼ばれることもある。

砂岩・磻岩層は基底あるいは縁辺相で，本地域東縁部 に厚く発達している。啋岩の碩は周辺の後背地の基盤岩 からもたらされたもので，一般に移動距離はきわめて短 かいと考えられる。

泥岩層は，粗粒岩層の中に挟まれて発達するものもあ
るが，主として，粗粒岩や火山砕屑岩類を怙括って全域 に発達している。五十風川上流地域，見附油田周辺や三 川盈地などでは，泥岩層がこれらの岩層に急激な側方変 化をしている。

浮遊性有孔虫化石層序では，Globorotalia fohsi 带 に属し, これは最近の研究によって(1)帯から回帯に細分 されている。

底棲性有孔虫化石群集は Hopkinsina morimachiensis-Gyroidina orbicularis 帯に属する。主要な構成 種は Hopkinsina morimachiensis, H. sinboi, Pullenia bulloides, Gyroidina orbicularis, Sphaeroidina bulloides, Ammonia tochigiensis, Florilus kidoharaense, Sigmoilopsis schlumbergeri などで ある。

砂岩の部分には Miogypsina-Operculina フォーナ が認められる。貝化石群集は ArcidーPotamid フォー ナとPectinid フォーナが, 植物化石としては台島型フ ロラが産出する。いずれる本階を特徴づけるもので，他 地域との対比に有効である。

本階に属する地層は，北蒲原地区縁辺部に露出する岩 船層(群), 同地域から東蒲原地区に発達する津川層およ び加茂市東方に模式地のある七谷層と，これらの相当層 である。

第 I 階の地層の分布が限定されているため，本階の地 層が直接基盤岩を招扣っているところが多い。

五十嵐川上流の五百川凝灰岩層について行なわれた， フィッショントラック法による放射年代の測定值は 1400 万年 (西村進, 石油資源開発社外委託研究報告) で, 浮 遊性有孔虫化石群集の国際対比による年代とよく一致し ている。

\section{4. 第 III階（寺泊階）}

本階の地層は，いわゆる黒色泥岩の寺泊層 で代表さ れ，汪とんぞの場所で下位の地層から連続している。

浮遊性有孔虫化石層序では, Globigerina pachyderma (dextral)-Globigerina woodi 帯に属する。 しかし，この群集は産出する地域が限られ，かつ本階の 下部にしか認められず，全体としては浮遊性有孔虫化石 に乏しい階として特徵づけられる。

底棲性有孔虫化石群集は Spirosigmoilinella compressa 帯に属し，ほとんど砂質有孔虫のみから成る。 この帯はさらに2 分され, 上部は Spirosigmoilinella compressa-Martinottiella communis 亜帯で, $M a$ rtinottiella communis, Cyclammina pusilla, Haplophragmoides spp. などに Spirosigmoilinella compressa を伴なう。下部は Dorothia sp.-Haplophragmoides sp. 画帯で, これらの種の浪か Pulectina 
spp. を多量に伴なう。両亜带の区分は広域にわたって 追跡でき，それによって本階の地層を 2 分することがで きる。しかし, 紫雲寺ガス田のように, 近距離で両亚帯 の境界が不明になる所もあり，両者の違いは，本質的に は環境の差を示すものと考えられる。本論文では, 両車 帯が区分できる所についてのみ，断両面などに寺泊層上 部および下部として表現した。

弥彦山塊から中央油带東縁を結ぶ線より西方および南 方の地域では, Dorothia sp.-Haplophragmoides sp. 亜带の下部に Gyroidina cf. sordanii, Valvulineria nipponica, Casidulina norcrossi, Epistominella cf. pulchella, Globobulimina auriculata などの石灰質 種をかなりの頻度で含有している。吉井ガス田やその周 辺では，このような石灰質種の多産带が対比のよい手掛 りとなっている。

岩相は，ほとんどの地域で黒色泥岩である。しかし， 上述の石灰質底棲性有孔虫化石を産出する, 弥彦一中央 油帯以西の地域では，相当の砂岩層あるいは凝灭質砂岩 層が挟まれ，互層状を呈している。

火山砕屑岩は本地域の各所に知られている。長岡平野 では, 西長岡ガス田を中心に, 主として安山岩・石英安 山岩の活動が認められている。新津油田南方の丘陵地に 分布する火山岩類 (大沢山火山岩, 護摩堂山火山岩, 菩 提寺山火山岩）の大部分や，その南方の猿毛岳玄武岩質 安山岩も本階のものとされている。

弥彦山西方の間瀬玄武岩や，かつては岩船層中のもの とされていた村上市北方鰈山を中心に分布寸る安山岩 も，本階に属すると考文られる。

本階の地層の中には石英安山岩質の凝灰岩層が多数挟 まれており, 貯留岩となっているものもあって, 油田地 帯では固有の名称で呼ばれることがある。西山油田周辺 で寺泊層最上部にある別山凝灰岩層, 大河津分水で寺泊 層中部に挟まれている野積凝灰岩層などが著名である。 火山砕屑岩類は多いが，放射年代の測定は，大河津分 水の野積凝灰岩についてフィッショントラック法によっ て行なわれた(西村進, 石油資源開発社外委託研究報告) ものがあるだけで，その值は750万年となっている。本 階に対比れれる，秋田地域の船川層下部および女川層の 放射年代の測定値は，第 1 表に示してあるように， 870 万年ないし 1,300 万年となって拉，ややバラつきが大 きい。

\section{5. 第 IV 階（椎谷階）}

本階は西山油田周辺に標式的に露出している椎谷砂岩 - 泥岩互層と, 東山油田南方に分布している荒谷暗灰色 泥岩層で代表される。

浮遊性有孔虫化石群集 は“Orbulina” universa-
Globigerina woodi (s.1.) 帯に属 L, Globigerina pachyderma (dextral) を産する。底棲性有孔虫群集 では Miliammina echigoensis-Martinottiella communis 带に属し, これら両種のほか, Haplophragmoides spp. などの砂質種と, Uvigerina spp., Praeglobobulimina pupoides, Islandiella japonica, Cassidulina norcrossi などの石灰質種との混合群集 である。

具化石蚛 Solemiya tokunagai, Calyptogena nipponica, Conchocele bisecta, Serripes makiyamai などを産するが，示準的なものはない。

そのほか, Makiyama chitanii の繁栄期であること が本階の特徵としてあげられる。

岩相は砂岩・泥岩互層と暗灰色泥岩層が主たるすので あるが，両者は上下関係にあるものではなく，むしろ地 域的なものである。互層相はフリッシュと考えられるも のが多く, 西山一中央油帯, 長岡平野, 東山油帯, 西蒲 原平野, 新津油带などの地区に発達し, 泥岩相は五泉平 野の大部分，東山油帯南部などに分布している。

火山活動として, 長岡平野から東山油帯中〜北部にわ たる地域と, 七谷一下田丘陵地の南東部などに石英安山 岩の活動があり，後者に属するものには八木鼻石英安山 岩, 庭月集塊岩の個有名称がつけられている。加茂市周 辺の平野下にも，本階に属すると考光られる火山岩類が 発達している。

本階の堆積は, 大部分の地域では，前階にひき続いて 扣り，整合に累重しているが，北蒲原平野，新津油帯， 七谷一下田丘陵東部なぞでは，下位層との間に不整合が ある。

本階に属する岩層の放射年代は, 五十嵐川北岸の八木 鼻石英安山岩について西村進 ${ }^{94)}$, 鈴木正男がフィッショ ントラック法で測定し，580万年, 610 万年および710万年 の值を得ている。浮遊性有孔虫化石による国際対比 ${ }^{29)}$, 114) の年代とも比較的よく一致している。

\section{6. 第 $V$ 階 (西山階)}

本階の地層は暗緑灰色泥岩層を主とする西山層で代表 される。しばしば,ことに下部には, 砂岩・泥岩の互層 相，いわゆる浜忠互層が発達している。

互層相は, 後述する Globorotalia inflata 第 2 帯以 下に発達することが多く，この層準は Globigerina pachyderma の款の巻き方向が变化するところでもあ るので，本階を 2 つ区分すべきであるといら考え方も ある。しかし，互層相の発達はこれら微化石層序区分と 必ずしも一致せず，また，適当な鍵層もないので，本論 文では第 V階の細分はしなかった。ただ，岩相的に互層 相が明瞭に区分できるところでは，図上に区別して示し 
た。

浮遊性有孔虫層序では，本階の中～下部は Globige rina pachyderma (dextral)-Globorotalia inflata (s.1.) 帯, 上部は Globigerina pachyderma (sinistral)-Globigerina quinqueloba 带に属する。前者の 上部と下部には Globorotalia inflata を多産する部分 があり, 上部のものを Globorotalia inflata 第 2 帯, 下部のものを同第 3 帯と命名されている。

底棲性有孔虫化石層序では, Uvigerina akitaensisIslandiella japonica 帯に属し, Uvigerina akitaensis, U. spp., Trifarina kokozuraensis, Pullenia apertula, Valvulineria sadonica, Globobulimina auriculata などの石灰質有孔虫を産し, 砂質有孔虫の Haplophragmoides spp., Cribrostomoides cf. evo. luta などを伴なっている。

貝化石群集は岩層によって内容が異なり，泥質岩から は Conchocele bisecta, Acila nakazimai, Limopsis tajimae など, 砂質岩からは Glycymeris yessoensis, G. nipponica, Venericardia ferruginea などを産す る。

本階の地層は下位層から整合に累重するところが多い が, 西山・中央油带, 東山油带, 北蒲原平野東縁部など の地区では，基底に不整合の認められるところがある。

火山砕霄岩類の分布はかなり広い。括もなものは, 角 田山塊, 加茂市周辺の平野下, 長岡市周辺の平野下, 東 山油帯, 小千谷市西方の片貝丘陵深部などで, 地表ある いは地下に拀いて見られる。主として安山岩あるいは石 英安山岩類である。

放射年代の測定は，雲出ガス田の坑井コアなどについ て試みられたが，試料に適当なものがなく，测定結果は 報告されていない。本階に対比される秋田県男鹿半島の 脇本層打よび北浦層中の凝死岩の放射年代は，西村進 ${ }^{84)}$ の報告によれば，それぞれ 680 万年，750万年となって いる。浮遊性有孔虫化石を基準にした対比から考党られ る年代に比してやや大きい值である。

\section{7. 第}

灰色シルト岩を主とする死爪層が本階の代表的地層で あるが，一部に砂岩勝ちの岩相を呈する部分（和南津 層), 砂磁岩層の卓越する部分 (塚山層) がある。

浮遊性有孔虫化石の Globigerina pachyderma ( $\mathrm{si}$ nistral)—Globigerina incompta 带に相当するが, 最 下部には Globorotalia inflata, Grt. crassaformis, Grt. tosaensis を産することがあり, Globigerina pachyderma も右巻きのものが卓越する。これが Globorotalia inflata 第 1 带と呼ばれているものである。

底棲性有孔虫化石層序では, 本階は Protoelphidium
clavatum-Pseudorotalia gaimardii 帯に属する。 Islandiella japonica, Cassidulina norcrossi, Epistominella pulchella, Protoelphidium clavatum, Cribroelphidium yabei などが主要な構成種で, 下部 には Uvigerina spp., Trifarina kokozuraensisな ぞ, やや深海に生息する種を伴なっている。しかし, 砂 岩を主とする和南津層や塚山層では化石にそしく, Ammonia takanabensis, Florilus mampukujiensis, Siphogenerina raphanus などを局所的に産する。

貝化石についてみると, 灰爪層, 和南津層から Acila nakazimai, Macoma tokyoensis, Turritella saishuensis, T.s. etigoensis, Glycymeris yessoensis, G. nipponica, Anadara amicula, Patinopecten kurosawaensis, Spisula voyi, S. sachaliensis, Mercenaria yokoyamai, Limopsis tajimae, Umbonium akitanumなど，いわゆる大桑一万願寺フォー ナに対比される群集を産する。塚山層からはOstrea sp., Corbicula atalata, Barnea japonica など,か なり低棘水棲の貝化石を産する。

塚山層の上部から Parastegodon cf. akashiensis の 産出が知られている。凝灰岩層を対象にした放射年代の 測定 ${ }^{90)}$ では, 塚山層基序部の凝灰岩は 275 万年, 塚山層 中の凝灰岩が110ないし190万年, 塚野山凝灰岩層が85な いし100万年（いずれもフィッショントラック法）とい ら值を得でり, 象化石から推定される地質年代は確か らしく思われる。

本階の地層は，多くの場所で，下位の地層に整合で累 重しているが, 盈地縁辺の丘陵地域ではしばしば軽微な 不整合現象が観察される。

\section{8. 第项階（小国階）}

小国層で代表され，砂・磻・粘土から成る地層で，大 部分の地域では圧密・固化が進んでいない。

小国層と安田層からは Paleoloxodon namadicus naumanni の化石を産した。平野部に和いては, Ostrea sp., Corbicula sp. などの浅海や低感水域に生息する貝 化石を産し, 有孔虫化石もAmmonia japonica, Pseudorotalia gaimardii など浅海ないし瀕海棲の群集が 局所的に認められる。これらの海棲化石群集は, 全般的 に，現在の海岸付近から丘陵部に近づくにつれてより下 位の層準にのみ産出する。新潟堆積盈地の海退の状況を 示すものと考光られる。

下位の地層との間には多くの場合不整合があり，境界 は明膫であるが，平野部においては連続的に堆積したた め，境界が不明瞭になっているところが多い。

\section{9. 層序上の問題点}

本地域の新第三系と第四系下部を 7 つ階に区分した 
第 2 図北蒲原地区地質図

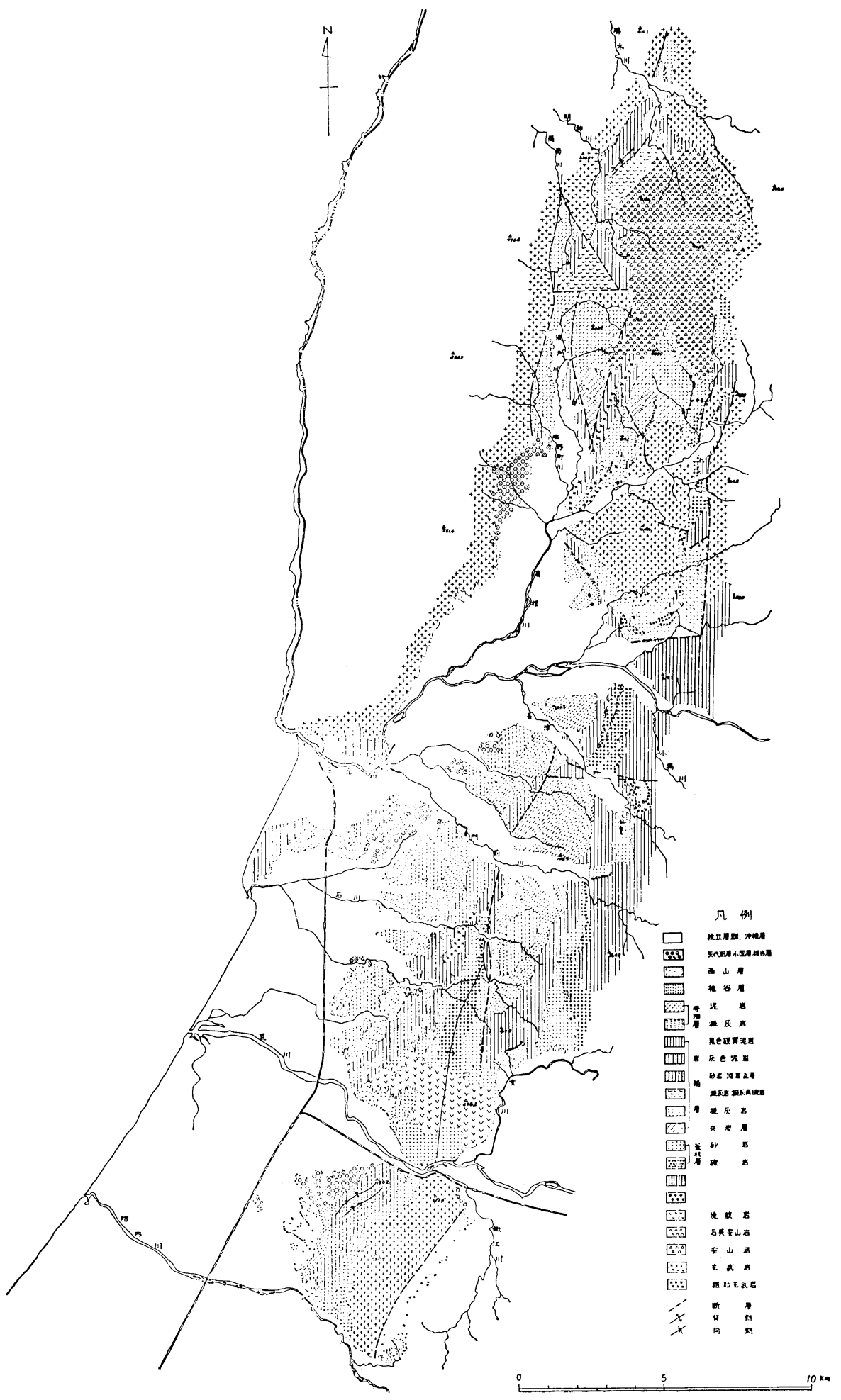


が，これについてはな和多くの問題が残されている。と くに今回新たに定義した第 II 階，第 点の主要なものについて述べる。

\subsection{1. 第 I 階に関する問題}

第 I 階の認定は，関植物化石群を産する佐渡島を除い て, 本土側ではやや根拠が弱い。今後, 花粉化石なぞに よって資料を補充し，検討すべきである。

\section{9. 2. 第 II 階，第 III階の設定と問題点}

従来，新潟地域の中新統中・下部の層序は，下位から 相川 (三川) 層群; 岩船層群; 津川層; 七谷層で，それ ぞれ, 阿仁合型フロラ; 台島型フロラとArcid-Potamid フォーナ; Pectinid フォーナと Miogypsina-Operculina フォーナ; Globorotalia fohsi フォーナと Hopkinsina フォーナで特徵づけられた独立の階に属する ものとされていた222,231,241,27),98)など。

1969年, 白井健裕 ${ }^{881}$ は, 村上市北方の岩船層群中の泥 岩層の底棲性有孔虫化石を研究し, その群集組成が秋田 地域の西黒沢層, 本地域の七谷層中のものに酷似するこ とを明らかにした。筆者は，同年にこの地方を概查し， 岩船層群に属するとされていた凝灭角碚岩層の最下部に Operculina sp. の産することを確認し（村上市北方約 $15 \mathrm{~km}$. , 薦川北方)，この地方の層序に疑問のあることを 指摘した (石油資源開発社内報告)。

一方, 七谷層と寺泊層の境界は底棲性有孔虫化石によ って決められていた。すなわち，上位の寺泊層では汪と えぞ砂質有孔虫のみから成る群集であるのに対し，七谷 層は砂質種のほかに，多数の石灰質種を含み，とくに特 徵種として Hopkinsina morimachiensis, H. simboi があり, 砂質有孔虫の Sigmoilopsis, schlumbergeri もとの特徴種とされていた。浮遊性有孔虫化石の検討が 進み，地表・坑井の資料を再検討したところ，Globorotalia fohsi が, 上述の Hopkinsina など七谷層の特 徵種である底棲性有孔虫に伴なって産出することが明ら かになり，七谷層は Globorotalia fohsi の産出をもっ て規定するのが妥当であるとの見解が出された（石油資 源開発社内資料之同会議資料)。これ関連して，中央 油帯とその周辺の地域では, 寺泊層の下部から砂質有孔 虫化石とともに多数の石灰質有孔虫化石を産するため, 一時は，七谷層に属するものであらうとされたが，石灰 質有孔虫化石の内容は，Hopkinsina などの示準的な要 素をむたないものであった。さらに，この層準の浮遊性 有孔虫化石群集は, Globigerina pachyderma, Gna. woodi などで, Globorotalia fohsi 群集とは明らかに 区別されるものであった。

その後 Globorotalia fohsi の細分によって，第 II 階 ・第正階に関して，下記の浮遊性有孔虫化石層序が確立
された。

(IV) Globigerina pachyderma (dextral)-Globigerina woodi (s.1.) 帯

(III) Globorotalia peripheroacuta-Globorotalia scitula gigantea 带

(II) Globorotalia peripheroronda-Globorotalia scitula praescitula 帯

(1) Globigerinoides sicanus-Praeorbulina curva 帯

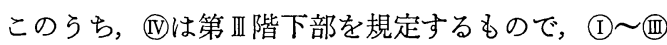
が従来の Globorotalia fohsi 帯である。

層序が最も混乱していた村上北方地域について，1971 年に猪間明俊・森田謙宏が調査し，従来とまったく異な る結果を得た (石油資源開発社内 報 告)。第 2 図・第 3 図に筆者が総合した北蒲原地区の地質図と地質柱状図を 示す。

第 3 図北蒲原地区地表地質柱状図

$$
\begin{gathered}
\text { C-4 } \\
\text { 览 } \\
\text { 监 }
\end{gathered}
$$

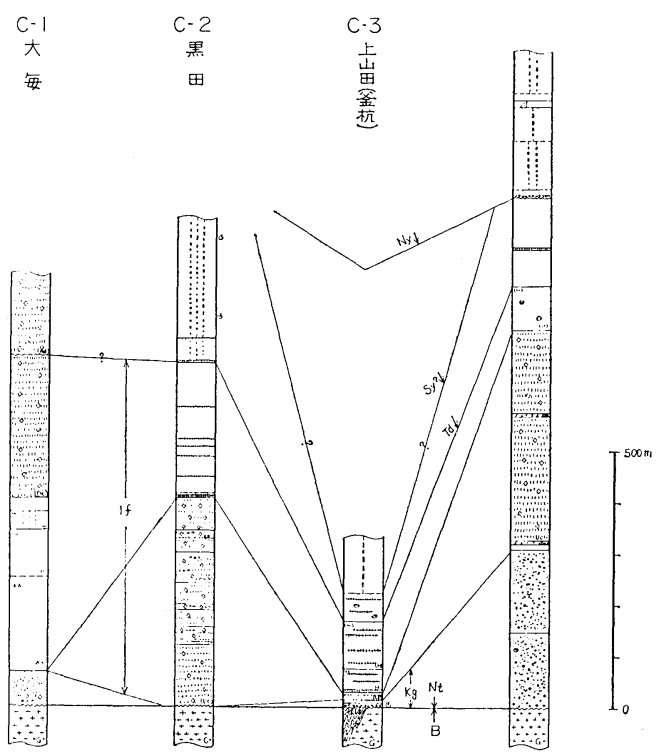

村上市東方，門前川流域では，基盤岩の上に釜杭花崗 砂磉岩層（従来津川層に対比）がのり，その上位は硬質 泥岩層になっている。前者にはMiogygsina-Operculina フォーナと Pectinid フォーナを産する。北方へ ゆくと，基盤岩の上飞㠜灰岩または凝灰角啋岩層（従来 岩船層群とされていた）がのり，その基底部付近から Operculina sp. が産出した。この凝灰岩層には，しば しば㩊炭層が挟まれて和り，その上位には大須戸層の泥 


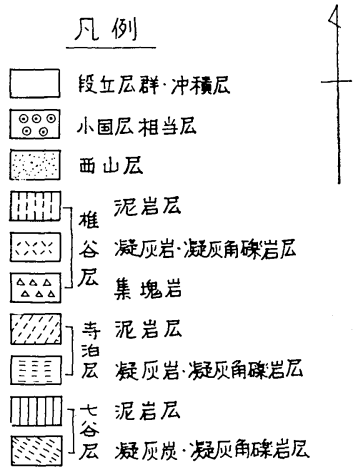

第 4 図 七谷一下田丘陵地質図

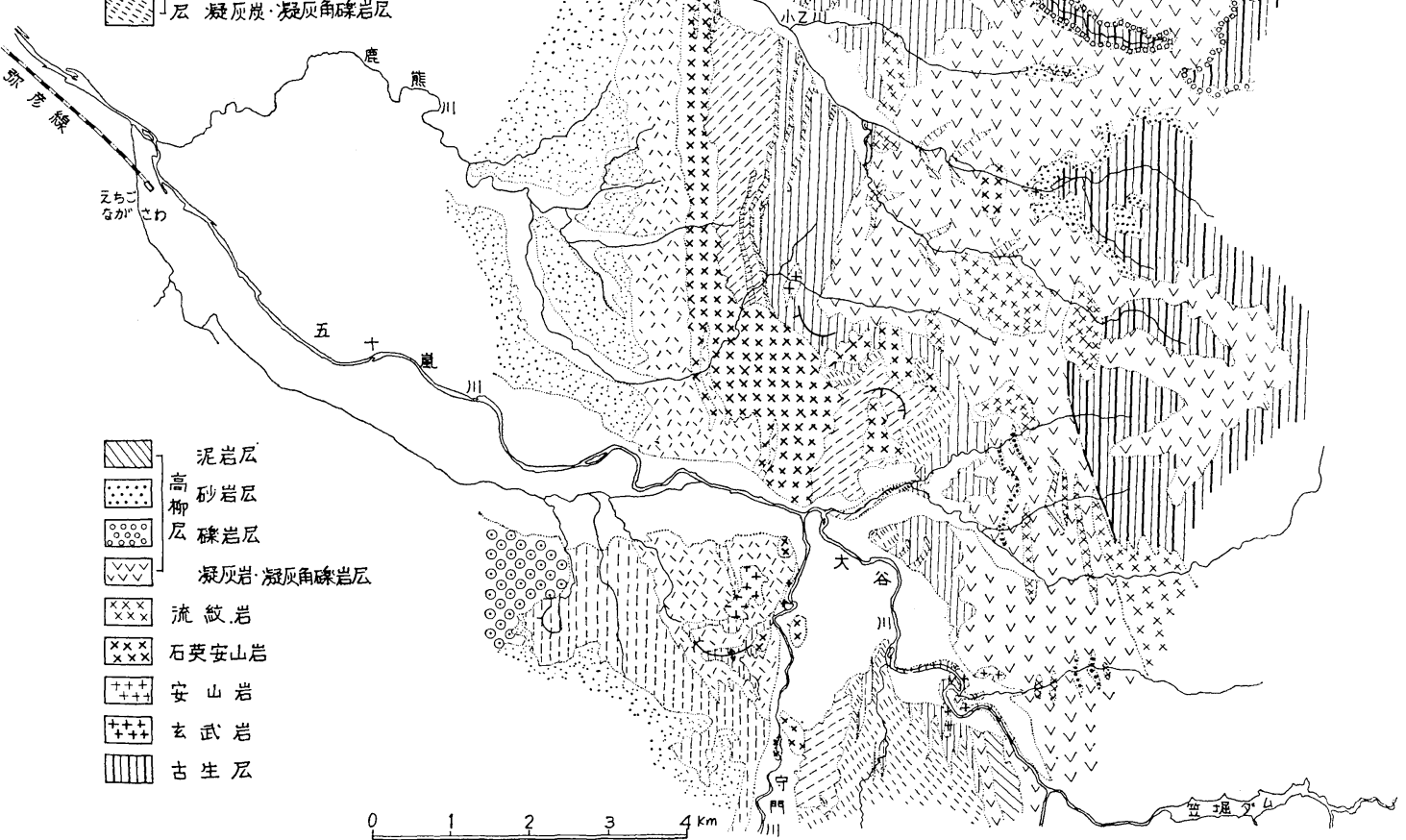

岩部層があって，この中に台島型フロラに対比される大 須戸化石植物群が含まれている。さらに北方, 大毎, 蒲 萄の地区では，基底碎岩層あるいは凝灰角碑岩層が基盤 の直上にあり，その上位に蒲萄層の泥岩部層が累重し， この中から浮遊性有孔虫の门帯, (1)帯が検出された。ま た, Globorotalia 属を産する泥岩層との層位関係は断 層と基盤岩の露出のために不明であるが，蒲萄付近にあ る，岩質の類似する泥岩層から Arcid-Potamidフォ 一ナが確認されている（西田彰一; 石油資源開発社外委 託調查報告)。

三川盈地では, Miogypsina-Operculina フォーナ を産する津川層のシルト岩層から，(1)帯に属する浮遊性 有孔虫化石群集が検出された。これより下位層準には， 台島型フロラの観音沢化石植物群の産出が知られてい る。
七谷層の模式地から五十㜄川上流地域の地質図と地質 柱状図を第 4 図と第 5 図示す。ここでは，高柳㠜灰岩 層（津川層に対比されていた）ょり上位の泥岩層から (I), (II), (III)の各帯に属する浮遊性有孔虫化石群集が確認さ れている。その上限は, 五百川凝灰岩層と呼ばれる乱堆 積状の凝灭岩層で, 五十風川以南の地域ではこの五百川 凝灰岩層以下の層準は, 急激に緑色酸性の凝灰岩相 (グ リンタフ）に側方変化している。

以上述べてきたことをまとめると，本項冒頭に示した 従来の中新統中・下部の層序は再編成されるべきで, 岩 船岩群, 津川層および七谷層は, その大部分が同一の時 代の地層であると解釈するのが妥当である。したがっ

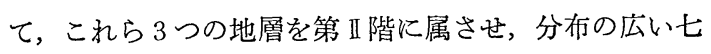
谷層をもって標準地層名とした。 
第 $\mathbf{5}$ 図七谷下田丘陵地質柱状図
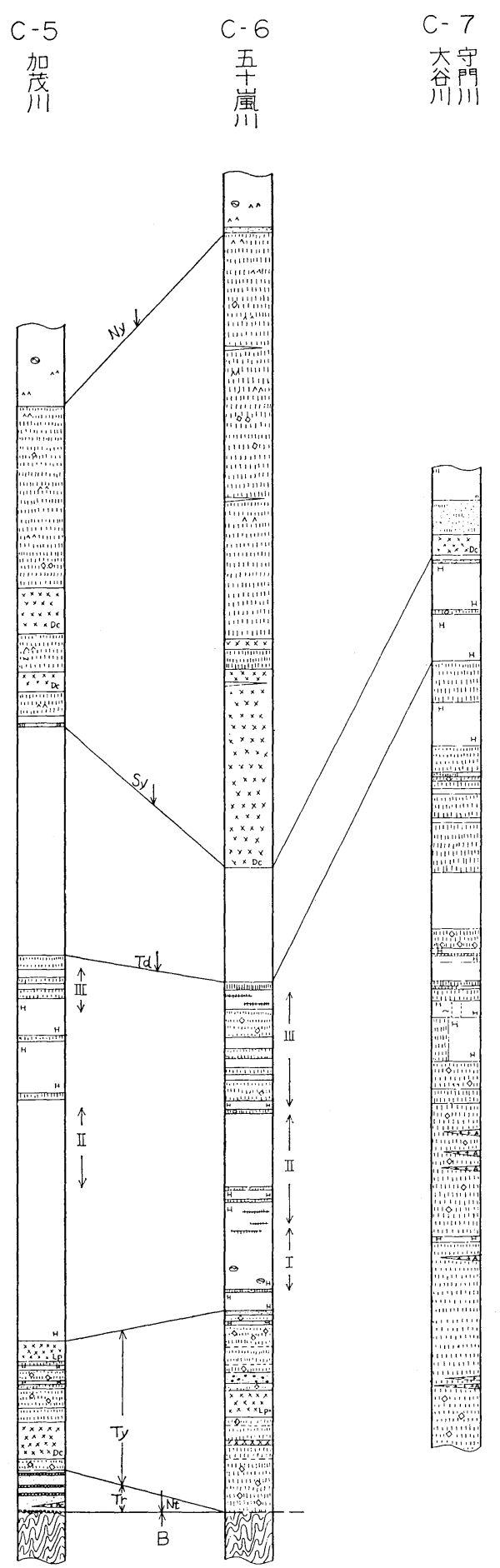

\section{凡例( $C_{1} \sim 4$ 上其通 $)$}

Ny 西山层

Sy 㩲谷尼

$T d$ 寺泊尼

$\mathrm{Nt} t$ 谷局

Lf 宸船尼

kg 釜杭磷岩层

Ty高柳凝䒚岩尼

Tr 户入䃏岩层

$\square$ 泥岩

$\vdots$ シルト岩

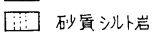

砂岩

요 磉岩

石炭

刑四凝原岩

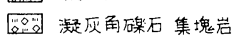

欧进入岩

世哃出崖

四粘板岩

(ब泥原面团球

$\square$ 㠜原筫妾示与

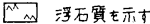

四硬留老示す。

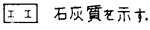

LP 流船岩

DC 石英安山岩

Bs 玄武岩

G 花画岩

I Globorotalia fohsi ブループ为 1 荤

$\begin{array}{lll}\text { II } & \text { 今 } & \text { 为 } 2 \text { 带 } \\ \text { II } & \text { 人 } & \text { 为了带 }\end{array}$

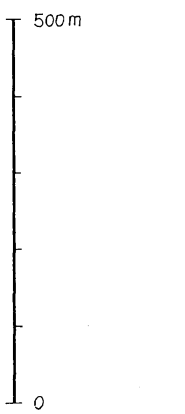


同じ東北裏日本堆積盆地の中にある秋田地域では，第 II 階に相当する地層は台島層と西黒沢層である。両層 は, 堆積相・化石相・火山岩の岩質などに差があるの で, 別々の階に属するものと考兄られて扣り, 本地域の 階区分と調和しない。この点については，今後の検討が またれる。

\subsection{3. 第 $\nabla$ 階と第 $\nabla$ 階に関する問題}

第 V階は浮遊性有孔虫化石 Globorotalia inflata 第 (3帯を基底として設定されて和り，この規定は，他の底 棲性和よび浮遊性有孔虫化石層序区分と調和している。 新潟平野など第 V階の地層が厚いところでは，一時， 西山階基底として第(2)帯を誤って用いていたが，Globigerina pachyderma の款の巻き方向の変化や，底棲性 有孔虫化石の再検討によって修正された。しかしなお， 第 IV階に属する地層から Globorotalia inflata の産出 する地域があるなど，幾らか問題が残っていた。

最近, 米谷盛寿郎は Gioborotalia inflata を Globorotalia ikebei, Grt. orientalis, Grt. inflata praeinflata, Grt. inflata inflata に細分した。これによ

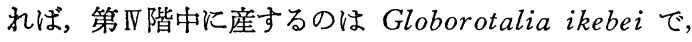
第(3)帯に産するものは Globorotalia orientalis, Grt. inflata praeinflata を主とし，第(2)帯は Globorotalia inflata praeinflata, Grt. inflata inflata であって, 問題は解決されたものと考えられる。しかし Globorotalia inflata の細分に関する研究はようやく緒につい たばかりであり，広域にわたる検討を進めている段階で あるので，本論文では日常用いられている浮遊性有孔虫 化石層序で記述を進めることとし，上記のような新事実 のあることを指摘するにとどめる。

\subsection{4. 第 $\nabla$ 階と第 $V I$ 階の区分}

第 $\mathrm{V}$ 階と第 $\mathrm{I}$ 階の区分は，最近，浮遊性有孔虫化石な その資料をとり入れて修正された。しかし，産出が十分 でないため, 実際の地層区分に当っては，底棲性有孔虫 化石層序や岩相層序に頼らざるをえない場合が多い。

2.9.5. 魚沼層群に関する問題

これまで，塚山層と小国層は一括して魚沼層群と呼ば れ，新潟堆積盆地末期の堆積層と考えられていた。1969 年, 石油括よび可燃性天然ガス開発促進審議会の資料 ${ }^{98)}$ 作成に際し，筆者は次のような理由により，塚山層を魚 沼層群から分離して灰爪層に含ませた。

（i）八石背斜周辺の地表調査 (片平忠実·大森隆一郎,
石油資源開発社内報告）により，八石背斜西翼・北沈降 部で和南津層中に挟まれている大広田凝灰岩層が，背斜 東翼で塚山層最上部に挟まれている塚野山凝灰岩層に連 続することが明らかになった。

(ii) 大広田凝死岩層の分布北限は長岡平野南部の雲出 ガス田で，ここでは，本凝灰岩層のすぐ上位にある顕著 な砂碟岩層以上を“魚沼層群”として取り扱ってきた。 これは模式地の小国層とされるもので，模式塚山層は， 長岡平野では，和南津層とされていたものの大部分に相 当する。

(iii) 新潟県各地で，従来“魚沼層群”およびその相当 層とされていた地層は，長岡平野の“魚沼層群”を基準 にして設定されていたものであり，模式地の小国層に相 当する。

平野部における，第 VI 階の岩相分布の状況を考える 之，灰爪層，和南津層，塚山層を別別の階として区分す るのは困難であり, 後 2 者は灰爪階中に局部的に発達す る岩相層序単元である。

\section{3. 時 代 論}

最近の放射年代测定結果の蓄積により，この地域の地 質年代も，いわば絶対年代で論じられる時代になってき ている。しかし，その測定結果は，部分的には信頼でき るもののように見えても，まだバラつきが大きい。資料 の数としても少ない。したがって，本論文では，浮遊性 有孔虫化石による汎世界的な対比を，放射年代の測定結 果によって一部修正し，第 1 表に示したような年代区分 をした。

本地域の中新統が，中新世のどの時期から始まってい るかは，示準化石の含有がなく，明らかでない。秋田地 域の放射年代の測定値から判断すると, 少なくとも中新 世の前期には及んでいると考えられる。

中新世と鮮新世の境界は，第 $\mathrm{V}$ 階と第 V階の境界にほ ぼ一致する。

魚新世と更新世の境界は，魚沼地方で測定された放射 年代の值を考慮して，第 階の上部に相当すると考学 た。地層でいうと, 塚山層の中に入るが，詳論するに足 る資料はない。（参考文献は続けて発表する予定の「新 潟県中越・下越地方の石油地質学的研究（その II）にま とめて示す) 